\title{
Environmental Safety Assessment of a Printing Plant in Cairo, Egypt
}

\author{
Abeer A. Ibrahim*, Mohamed S. Elgewely*, Sally A. Hakim*, Ghada O. Wassif* \\ * Department of Community, Environmental and Occupational Medicine, Faculty of \\ Medicine, Ain Shams University \\ Received: August $2018 \quad$ accepted: September 2018
}

\begin{abstract}
Background: The workplace environment impacts workers health, morale, productivity and engagement - both positively and negatively. The workplace environment in most of industry is unsafe and unhealthy. During the past ten years, the printing services have met a large development. Technological changes and the introduction of new work processes in the matter of printing have had a deep impact on labor, security and health.

Objectives: to describe the environmental features of a printing press in Cairo.

Methods: A descriptive observational study was carried out in a big printing press in Cairo, Egypt. Assessment of the work environment (prepress department, printing department, bookbinding section \& office) was done using checklist modified from that of occupational safety team, 2012. Results: The majority of the study participants (79.5\%) in the printing press were working in the printing and bookbinding department. which complains from poor ventilation, poor housekeeping, presence of spills \& tripping hazards, lack of personal protective equipments, presence of noisy machines, significant manual handling \& awkward body positions, lack of first aid kit \& hazardous containers (ink containers in the printing department $\&$ adhesives in the bookbinding department) were left open. By comparing the departmental total score of the items in the environmental checklist; the prepress department were the highest in fulfilling the positive items with score $(86.66 \%)$ and the printing \& bookbinding department were the least with total score $(40.09 \%)$. Conclusion: The study concluded that some areas of the printing press (printing \& bookbinding department) need urgent attention to the work environment and recommend periodic environmental examination, good housekeeping, training, health education \& provision of protective measures. Further work to confirm these findings in other study settings \& population is also needed.
\end{abstract}

Key words: printing press - work environment - safety measures Corresponding author: Dr Ghada Osama Wassif

E-mail: ghada_wassif@yahoo.com

\section{Introduction}

Printing presses differ by type and size, ranging from relatively simple manual presses to the complex large presses used for printing newspapers, magazines and books. Printing presses include also cutting, binding, folding and finishing equipments. However, many modern printing presses depend on computer controls ${ }^{(1)}$. Lithography is by far the most widely practiced paper printing technique in the local market ${ }^{(2)}$. Prepress / Imaging is the process used to produce an image, through electronic devices and software, of the subject to be printed on automatic plate. Computer-to-plate (CTP) 
technologies have replaced traditional plate making so eliminate the use of many hazardous chemicals ${ }^{(3)}$. Offset printing requires cleaning solutions of solvents to clean the press and other parts from dried inks. Post press / finishing involves cutting, folding and perforating steps. Book binding may use a variety of adhesives as well as many types of plastic or metal bookbinding items (e.g. metal stitches and wires) ${ }^{(2)(3)}$. Each of these processes possesses hazards to workers. According to ILO,2008, workers in printing press are exposed to physical, chemical, mechanical, biological and psychological hazards beside accidents with all its sequels ${ }^{(4)}$.

Many key principles support the field of occupational health and safety. Among these principles; the vital objective is 'work should take place in a safe and healthy environment' ${ }^{(5)}$. So, workplaces and working environments should be planned and designed to be safe and healthy. Efforts essentially are focused on primary prevention at the workplace level ${ }^{(6)}$.

Environmental factors such as temperature, lighting, ventilation, poor housekeeping, ill-structured jobs, mismatch between worker capabilities and job demands, poor human-machine system design and inappropriate management programs are factors which may leads to workplace hazards, poor worker health, mechanical equipment injuries, disabilities and this can reduce worker productivity and work quality beside increases the cost ${ }^{(7)}$. Improving worker productivity, occupational health and safety (OHS) through adequate preventive and control measures in which the environment is a cornerstone, are major concerns of industry, especially in developing countries ${ }^{(8)}$. This study aimed to describe the environmental features of a printing press in Cairo in term of general work environment, housekeeping, floor, means of exit, personal protective equipments, machine guarding, noisy machines, fire protection, electrical safety, manual handling, first aid, waste handling, storage and signs posters.

\section{Material and Methods}

A cross sectional study was carried out at one of the most important printing presses in Cairo, Egypt. It is one of the most reputable \& important newspaper in Egypt that publish huge amount of copies every day. The newspaper is located in Cairo's city Centre. This printing press is not only famous for publishing newspaper but also for school $\&$ university books. Data was collected using checklist about the environmental hazards; assessing general work environment (building in good repair, lightening \& ventilation), housekeeping (work area clean \& ordered, spilled materials cleaned immediately), floor (slip resistant, free of tripping hazards), means of exit (present \& marked), personal protective devices (present, meet safety requirement), machine guarding (moving part guarded), fire protection (present), electrical safety (no bare electrical wires), manual handling (manual handling activities, manual handling equipments, awkward body postures), noisy machines, first Aid (present), waste handling (rubbish, empty carton and paper disposed of immediately), storage (hazardous substances properly labeled and safely stored) and sign posters (available). The checklist about environmental hazard assessment was adopted from a checklist 
issued by the occupational safety team,

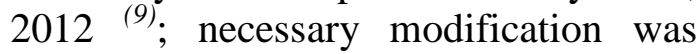
carried out on the checklist to adapt it for use in the studied printing press. The checklist checked the prepress department, CTP, printing press, bookbinding department \& office environment. Each item score and the total department score are calculated by summation of the positive responses divided by the no of departments for the first or total number of items for the second. These scores are reported as percentages.

\section{Ethical Consideration}

The protocol was submitted for ethical approval from the Institutional Review Board in Faculty of Medicine, Ain Shams University. Administrative Approval; permissions for study conduction were obtained from the printing press Board of Directors Chairman. Confidentiality of data was maintained and used only for scientific purposes.

\section{Results}

The results of the environmental examinations of the studied departments are present in table (1)

Regarding ventilation; (40\%) of the printing press had good ventilation (natural or mechanical means e.g. air conditioner \& windows. No odors). CTP, printing \& bookbinding department had poor ventilation. However, there were windows \& suction ventilation systems, but they were not enough to eliminate the solvents \& ink vapor as the vapors of the chemicals were not eliminated.

Good housekeeping (cleanliness, keeping work areas ordered, free of slip and trip hazards, and removing of waste materials) was in $(40 \%)$ of the printing press areas. Press \& post press areas were not clearly ordered \& need attention toward housekeeping. There were spills of the cleaning solvents used to clean the machines from dried inks in the press \& post press areas that may lead to slips.

The floor of the printing press was slip resistant \& free of tripping hazards in $(60 \%)$ of the areas. There were some floor \& stairs in the press \& post press may lead to slippage particularly in the presence of spills of cleaning solvents. The work place must have pathways free from any obstacles. Tripping hazards/obstacles were present in printing \& book binding department; where containers \& pallets of papers were in every place. Personal protective equipments (PPEs) were not present in the institution at all. The machines were guarded in the printing and book binding department.

Noisy machines were present in the printing and book binding department. There were manual handling activities as lifting, pulling \& pushing although there were conveyors that reduce some of the manual handling activities in the printing and book binding department. There was no first aid kit in CTP, press, post press $\&$ the offices. The paper waste, cartoons $\&$ containers were not immediately disposed and left in the work areas in CTP, press \& post press areas. Hazardous substances as inks \& solvents were left opened in the CTP, press \& post press areas that may lead to over exposure. A score was calculated for each department as how many items were fulfilled from all items in the environmental checklist. By comparing total score of the items in the checklist; the prepress department were the highest 
in fulfilling the items with score $(86.66 \%)$ and the printing \& bookbinding department were the least with total score (40.09\%) (Figure 1)

\section{Discussion}

The printing industry includes complex operations organized into distinct departments. Some operations involve large machinery, moving parts, volatile chemicals, and heavy containers ${ }^{(10)}$.

Wearing PPEs and local ventilation in the printing industry was associated with lower prevalence of eye irritation, rhinitis, and allergic skin reactions ${ }^{(11)}$. In the current study the PPEs were not available \& thus no one in the printing press was wearing PPEs. This in agreement with Shama, 2009 \& Goldberg et al 2006; where the PPEs were not available ${ }^{(12)(13)}$. In contrast to Arezes \& Miguel, 2005; Reinhold \& Tint, 2016 and $\mathrm{Yu}$ et al, 2005; where the PPEs were available all the time, but some workers didn't wear them as they believe that PPEs were not comfortable $\&$ interfere with work ${ }^{(14)(15)(16)}$.

The present study found that there was periodic maintenance for the machines every day and many of the machines are guarded e.g. guillotines. This was consistent with Starovoytova, 2017; where she stated the majority of the workers reported that the work equipment and machinery regularly checked to ensure that it works properly and that the guards are in good condition and operating correctly ${ }^{(17)}$.

Good ventilation systems in printing industry are essential to decrease workers' exposure to different hazards (18). Decharat, 2014 concluded that air ventilation system and PPE use were statistically significantly associated with the prevalence of acute symptoms ${ }^{(11)}$. Windows and suction ventilation systems were present in the studied printing press, but they weren't sufficient in elimination of the chemical vapors. Shama, 2009 also found that windows were the only way used for ventilation in the 10 visited print shops. Despite of this, the great majority of his sample (98.4\%) was not keen to open the widows for good ventilation (12). This may be due to unawareness of the importance of good ventilation.

While observing the work practices; some work processes and practices that put employees at risk for chemical exposure were noticed. These practices noted as having risks for chemical exposures included open containers of chemicals, spilled chemicals, bare hands in contact with chemicals, and inappropriate waste disposal methods. These also were observed by Casey \& Hawley, 2015 during the NIOSH visit to a commercial offset printing company upon a request for health hazards evaluation from the employees ${ }^{(19)}$.

It was observed, that the departments were lacking first-aid boxes. Agbenorku et al, 2012 reported that the majority of printing companies in Ghana do not have full-time health and safety managers. In a case of injury, a form of first aid is usually given by a colleague worker if there is any. The investigators discovered that there were no documented records on diseases affecting workers in the printing industry (20).

In general, all the examined departments were suffering to a varying degree from environmental hazards, So, prevention and control is a mandatory maneuver 
Prevention is based on environmental monitoring to control and attenuate exposure to causal agents (substitution, confinement, isolation, and exhaustion), intervention in the organization of work (reduction in the number of environmental stressors, number of persons exposed, and duration of exposure), practice of body and environmental hygiene, periodic medical examinations, training, and use of individual protective equipment (masks, respirators, filters, and air supplies) ${ }^{(21)}$.

\section{Study limitations}

The study was done in a large printing press that belong to the governmental sector where many safety rules that meet the safety standards are applied with modern machines, but this can't be generalized to the printing shops that belong to the private sector.

\section{Conclusion}

The study shows that each department in the studied press needs more attention to one or more of the environmental hazards especially at the printing \& bookbinding departments.

\section{Recommendations}

Provision of personal protective equipments to the workers, periodic environmental examination for different departments, educating \& training the workers about the hazards they are exposed to and how to deal safely with it and use of cleansing solutions and solvents containers of lower volatility are extremely necessary. Good housekeeping can prevent many health hazards.

\section{Acknowledgements}

The authors wish to express their greatest appreciation and utmost gratitude to the press board of directors and the studied participants.

\section{Funding}

This research did not receive any specific grant from funding agencies in the public, commercial, or not-for-profit sectors.

\section{References}

1. Utica National Insurance Group (2005) Hazards of Printing Presses Available at: http://www.uticanational.com/protection /riskmanagementalerts/documents/hazar ds\%20of\%20printing\%20presses.pdf

2. Occupational safety and health branch, Labour department (2004). Chemical safety in the workplace. Guidance notes on the chemical safety in printing industry. (1st Edition). Hong Kong: Occupational safety and health council. Available at: http://www.labour.gov.hk/text_alternati ve/pdf/eng/GN Printing.pdf

3. International finance corporation (IFC) (2007), Environmental, health and safety Guidelines for printing, Available at: https://www.ifc.org/wps/wcm/connect/2 59f4a00488559e18464d66a6515bb18/Fi nal++Printing.pdf?MOD=AJPERES\&id=13 $\underline{23152584582}$

4. International Labor Office (ILO). 2008, International Hazard Datasheets on Occupation: Printers. Available at: http://www.ilo.org/public/english/protec tion/safework/cis/products/hdo/htm/printer.htm -

5. Alli B (2001). Fundamental principles of occupational health and safety $\left(1^{\text {st }}\right.$ ed.) (17-20) Geneva (Switzerland): International Labor Office. Available at: 
http://univer.nuczu.edu.ua/tmp_metod/1 026/FUNDAMENTAL\%20PRINCIPLE S\%20OF\%200CCUPATIONAL\%20H EALTH\%20AND\%20SAFETY.pdf

6. Sorensen G, Barbeau EM, Stoddard AM, Hunt MK, Kaphingst K, Wallace L. (2005) Promoting behavior change among working-class, multi-ethnic workers: results of the Healthy Directions - Small Business Study. Am J Pub Health. 2005;95(8):1389-1395.

7. Chandrasekar K (2011). Workplace environment and its impact on organizational performance in public sector organizations. International Journal of Enterprise Computing and Business Systems, 2011; 1(1), Available at:

http://www.ijecbs.com/January2011/N4J an2011.pdf.

8. Vashnee M \& Rajesh D (2016) Analysis of Ergonomics and Identification of Root Causes of Construction Accident in Tamil Nadu. International Journal of Engineering and Management Research.6(2):773-780

9. Hardaker C, Galt J, Pullen K, Sayles L and Varley A (2012) Assessment Checklist of Home Environment for Flexible Home nvironment for Flexible/Home sposedrationogical symptoms, digestive system, urinary system \& tumors)Working Issued by Occupational Safety Team, Available at: https://www.bradford.gov.uk/hands/docu ments/New\%20Ways\%20of\%20Workin g/Assessment\%20Checklist $\% 20 \mathrm{of} \% 20 \mathrm{H}$ ome\%20Environment.pdf

10. Leiter M.P, Zanaletti W, Argentero $\mathbf{P}$ (2009) Occupational risk perception, safety training, and injury prevention: Testing a model in the Italian printing industry, J. of Occup. Health Psych., vol.14(1):1-10.
11. Decharat S. (2014) Prevalence of Acute Symptoms among Workers in Printing Factories. Advances in Preventive Medicine Volume 2014, Article ID 854052. Available at:

https://www.hindawi.com/journals/apm/ $\underline{2014 / 854052 /}$

12. Shama ME (2009) Perceptions and practices regarding Occupational hazards and safety measures among printing workers. Egyptian Journal of Occupational Medicine 33 (2):155-174

13. Goldberg A, Dar-El E and Rubin A (2006) Threat perception and the readiness to participate in safety programs. Journal of organizational behavior, 12 (2): 109-22.

14. Arezes $\mathbf{P}$ and Miguel A (2005). Individual perception of noise exposure and hearing protection in industry. Human Factors, 47(4):683-692.

15. Reinhold K \& Tint P, (2008), hazard profile in manufacturing: determination of risk levels towards enhancing the workplace safety, Journal of environmental engineering and landscape management 2009 17(2): 6980

16. Yu IT, Lee NL and Wong TW (2005) Knowledge, attitude and practice regarding organic solvents among printing workers in Hong Kong. J Occup Health., 47 (4):305-310.

17. Starovoytova D. (2017). Hazards and Risks at Rotary Screen Printing (Part 3/6): Psychosocial and Mechanical exposure. Industrial Engineering Letters 7(6) 2017

18. World Bank Group. Environmental, health and safety guidelines for printing (2007). Available at: http://www.ifc.org/ifcext/enviro.nsf/Atta chmentsByTitle/gui_EHSGuidelines200 7_Printing/\$FILE/Final+-+Printing.pdf 
19. Casey M, Hawley B (2016) Centers for Disease Control and Prevention (CDCP). Evaluation of Legionnaires' disease risk and other health hazards at an offset printing company, Health Hazard Evaluation Report. Available at: https://www.cdc.gov/niosh/hhe/reports/p dfs/2015-0065-3252.pdf

20. Agbenorku M., Johnson OA, Johnson OA, Nyador E, Agbenorku M, (2012). A Prospective Study of Diseases Associated with Workers in the Printing Industry in a City of Ghana. Science

22. and Lange, Stanford, Conn, USA, 2nd edition, 1997.
Journal of Medicine \& Clinical Trial (2014). Available at:

https://pdfs.semanticscholar.org/37d8/0f 20fd07e7e4a48360e897ee16fb0e63794a . pdf

21. Shusterman D (1997) "Upper respiratory tract disorders," in Occupational and Environmental Medicine, J. LaDou, Ed., pp. 291-304, Appleton 
Table (1): Comparing the work environment among different printing departments.

\begin{tabular}{|c|c|c|c|c|c|c|}
\hline Items & Prepress & STP & $\begin{array}{l}\text { Printing } \\
\text { press }\end{array}$ & gost & Office & Score \\
\hline \multicolumn{7}{|l|}{ General Work Environment } \\
\hline $\begin{array}{l}\text { 1- Building in good repair (maintaining sanitary } \\
\text { facilities. painting and cleaning walls. Broken } \\
\text { windows, damaged doors and broken floor } \\
\text { surfaces) }\end{array}$ & & V & & & V & $60 \%$ \\
\hline $\begin{array}{l}\text { 2- Lighting (All areas are adequately lit, adequate } \\
\text { at the place of work for the operation or work } \\
\text { performed) }\end{array}$ & & V & $\mathrm{V}$ & V & V & $100 \%$ \\
\hline $\begin{array}{l}\text { 3- Ventilation (Ventilation system e.g. exhaust } \\
\text { equipment, windows, air conditioner adequate, no } \\
\text { volatile chemical emissions) }\end{array}$ & & & & & V & $40 \%$ \\
\hline \multicolumn{7}{|l|}{ Housekeeping } \\
\hline 1- The work area clean \&orderly arranged & V & & & & 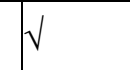 & $40 \%$ \\
\hline $\begin{array}{l}\text { 2- Spilled materials, trash and debris cleaned } \\
\text { immediately (Spillage of toxic substances shall be } \\
\text { removed as quickly as possible by the best } \\
\text { technical means possible.) }\end{array}$ & & & & & V & $40 \%$ \\
\hline \multicolumn{7}{|l|}{ Floor } \\
\hline 1- Floors are slip resistant (flat, even and dry) & V & V & & & W & $60 \%$ \\
\hline $\begin{array}{|llll|}\begin{array}{l}\text { 2-The workspace } \\
\text { hazards/obstacles }\end{array} & \text { free } & \text { of } & \text { tripping } \\
\end{array}$ & & V & & & $V$ & $40 \%$ \\
\hline \multicolumn{7}{|l|}{ Means of exit } \\
\hline 1- Exit to allow escape & V & V & V & V & V & $80 \%$ \\
\hline 2- Exits clearly marked & $V$ & V & $\sqrt{ }$ & V & V & $80 \%$ \\
\hline \multicolumn{7}{|l|}{ Personal protective devices } \\
\hline $\begin{array}{l}\text { 1- PPEs (goggles, aprons, gloves, face mask, } \\
\text { footwear \& hearing protection) }\end{array}$ & & & & & & $0 \%$ \\
\hline 2- Required equipment meet safety requirement & & & & & & $0 \%$ \\
\hline \multicolumn{7}{|l|}{ Machine guarding } \\
\hline $\begin{array}{l}\text { belts, pulleys, gears, shafts and moving parts } \\
\text { guarded to prevent accidental contact }\end{array}$ & & & V & $\sqrt{ }$ & & $100 \%$ \\
\hline \multicolumn{7}{|l|}{ Noisy machines } \\
\hline No noisy machine that produce excessive noise & & & V & V & & $100 \%$ \\
\hline
\end{tabular}


Table (1) cont.: Comparing the work environment among different printing departments.

\begin{tabular}{|c|c|c|c|c|c|c|}
\hline Items & Prepres & $\mathbf{S T P}$ & $\begin{array}{l}\text { Printing } \\
\text { press }\end{array}$ & $\begin{array}{l}\text { gost } \\
\text { press }\end{array}$ & Office & Score \\
\hline \multicolumn{7}{|l|}{ Fire Protection } \\
\hline Fire extinguishers present to do the job & $\sqrt{ }$ & $\sqrt{ }$ & $\sqrt{ }$ & V & V & $100 \%$ \\
\hline \multicolumn{7}{|l|}{ Electrical safety } \\
\hline No bare electrical wires & $\sqrt{ }$ & V & $\sqrt{ }$ & V & V & $100 \%$ \\
\hline \multicolumn{7}{|l|}{ Manual Handling } \\
\hline $\begin{array}{l}\text { No significant manual handling activities that } \\
\text { cause injury (heavy lifting, pushing, pulling) }\end{array}$ & & V & & & & $0 \%$ \\
\hline $\begin{array}{l}\text { Manual handling equipment is readily available } \\
\text { for moving heavy equipment e.g. trolleys }\end{array}$ & & & $\sqrt{ }$ & V & & $100 \%$ \\
\hline No awkward body postures & & & & & & b\% \\
\hline \multicolumn{7}{|l|}{ First Aid } \\
\hline a suitable First Aid kit present & $\sqrt{ }$ & & & & & $20 \%$ \\
\hline \multicolumn{7}{|l|}{ Waste Handling } \\
\hline $\begin{array}{l}\text { Rubbish, empty carton and paper disposed of } \\
\text { immediately }\end{array}$ & & & & & V & $40 \%$ \\
\hline \multicolumn{7}{|l|}{ Storage } \\
\hline $\begin{array}{l}\text { Hazardous substances properly labeled and safely } \\
\text { stored (All containers with hazardous substances } \\
\text { shall be properly labelled.) }\end{array}$ & & & & & & $0 \%$ \\
\hline \multicolumn{7}{|l|}{ Signs posters } \\
\hline Signs posters available in the workplace & & & $\sqrt{ }$ & $\sqrt{ }$ & $\sqrt{ }$ & $60 \%$ \\
\hline Total score & $13 / 15$ & $9 / 19$ & $9 / 22$ & $9 / 22$ & $13 / 15$ & \\
\hline$\%$ & 86.7 & 47.3 & 40.1 & 40.1 & 86.7 & \\
\hline
\end{tabular}

$(\sqrt{ })=$ available / present

Empty cell $=$ not available $/$ not present

Shaded areas $=$ not applicable 


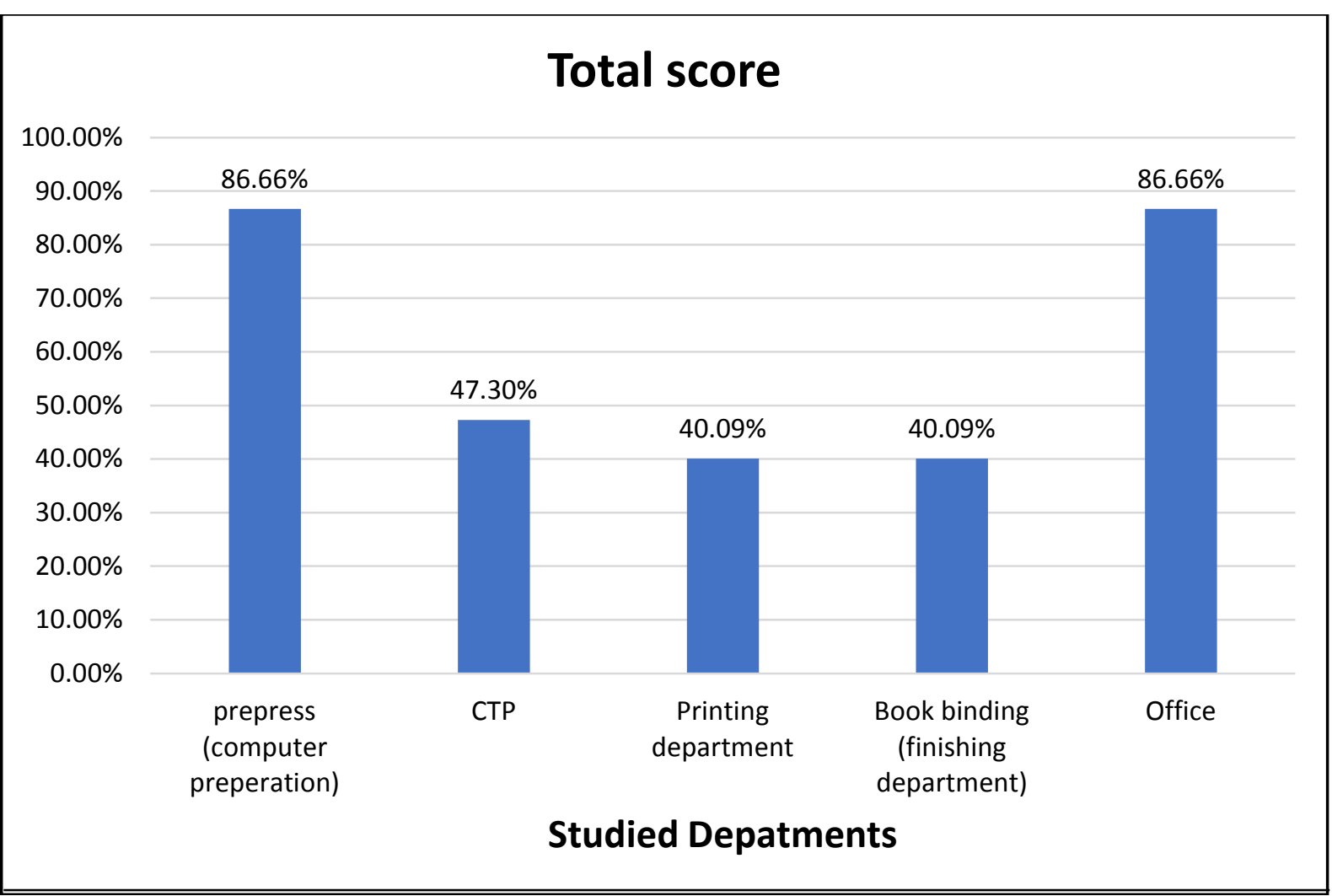

Figure (1): Total score for environmental safety in the different studied departments. 